Instructions for authors, subscriptions and further details:

http://rise.hipatiapress.com

\title{
Rancière: Pedagogy and Politics
}

David Ernest Harris ${ }^{1}$

1) University of St Mark and St John

Date of publication: June $25^{\text {th }}, 2015$

Edition period: June 2015-October 2015

To cite this article: Harris, D.E. (2015). Rancière: Pedagogy and Politics. International Journal of Sociology of Education, 4(2), 158-181. doi: 10.17583/rise.2015.1479

To link this article: http://dx.doi.org/10.17583/rise.2015.1479

PLEASE SCROLL DOWN FOR ARTICLE

The terms and conditions of use are related to the Open Journal System and to Creative Commons Attribution License (CC-BY) 



\title{
Rancière: Pedagogy and Politics
}

\author{
David Ernest Harris \\ University of St Mark and St \\ John
}

(Received: 18 March 2015; Accepted: 23 May 2015; Published: 25 June 2015)

\section{Abstract}

Rancière's work on education is becoming widely known, but it must be understood in its context to avoid any misleadingly conventional readings and to grasp its general importance. The work on industrial history is obviously connected, but so are the more technical academic criticisms of Althusser, Bourdieu and Marx. These add considerably to conventional discussion by identifying a crucial contradiction between emancipatory goals and necessary hierarchies based on expertise. Rancière's work on aesthetics as a democratic arena has inspired some recent educational experiments in participation. His historical research can also be seen as providing support for current educational struggles against neoliberalism. Rancière's methods are assessed critically in turn, and the connections with Foucault can be seen to both unify the work overall and raise difficulties of its own.

Keywords: Rancière, Althusser, Bourdieu, emancipatory education, Foucault, Marx 
RISE - International Journal of Sociology of Education Vol. 4 No. 2 June 2015 pp. 158-181

\title{
Rancière: Pedagogía y Política
}

\author{
David Ernest Harris \\ University of St Mark and St \\ John
}

(Recibido: 18 Marzo 2015; Aceptado: 23 Mayo 2015; Publicado: 25 Junio 2015)

\section{Resumen}

La obra de Rancière sobre educación se está llegando a conocer ampliamente. Pero debe entenderse en su contexto para evitar lecturas falazmente convencionales y para aprehender su importancia general. Su trabajo sobre historia industrial está obviamente relacionado, así como lo están las críticas a Althusser, Bourdieu y Marx. Éstas contribuyen considerablemente a las discusiones convencionales al identificar contradicciones cruciales entre los objetivos de emancipación y la jerarquía necesaria basada en el conocimiento. El trabajo de Rancière sobre estética como esfera democrática ha inspirado algunos experimentos educacionales recientes sobre participación. Su investigación histórica también puede verse como un apoyo a las presentes luchas de la educación contra el neoliberalismo. Se evaluarán rigurosamente los métodos de Rancière en orden, y sus conexiones con Foucault, las cuales al mismo tiempo unifican la obra en general y presentan dificultades propias..

Palabras clave: Rancière, Althusser, Bourdieu, educación emancipadora, Foucault, Marx 


\section{Harris - Rancière: Pedagogy and Politics}

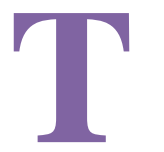

he Ignorant Schoolmaster (Rancière, 1991) concerns the activities and principles of Joseph Jacotot, an educationalist in Belgium and France in the 1830s. Rancière merges his voice with that of Jacotot in an interesting way in his account. Jacotot and the students had no shared language, and Jacotot began by giving them a popular classic text published in both French and Dutch. Students had to memorise each page of the text to teach themselves French and were regularly tested on their knowledge. To his surprise, apparently, Jacotot found that students were able to develop fluency in French using this method. External assessors agreed that students had produced work of an acceptable quality.

Jacotot/Rancière argued that people were perfectly capable of learning for themselves without the usual skilled pedagogy, therefore. Indeed, they learned even if pedagogues themselves knew nothing about the subject. There must be a fundamental equality of intelligence among human beings of whatever social station. Knowledge could also be developed in any direction by a process of linking the new to what was known already. Both claims contrast strongly with those of conventional models which involved specialist skilled and sequential explication.

Rancière's comments look like the well-established attack on traditional methods of teaching, another confirmation of the fundamental intelligence, equality, and creativity of children The idea that emancipatory knowledge can be developed from making connections between what is known and unknown can seem like one of the classic defences of non-disciplinary 'discovery' or project-based pedagogies.

However, Jacotot/Rancière also suggests features that would not be so popular with modern progressives. There is a demand that students undertake rote learning, for example, and be tested frequently on their knowledge. This is learning focused on definite objects or images, on 'a third thing - a book or some other piece of writing - alien to both [parties] and to which they can refer' (Rancière 2011b, p. 15). There are no excuses: rote learning was boring, for example, but student laziness had to be countered. When students dismissed academic learning as elitist, Jacotot pointed out that their own pride in their common sense or their practical expertise was also elitist, and, very often, showed strong contempt for 'ordinary people'. 
Most current educational thinking would see possessing technical or academic knowledge as the only acceptable basis for authority. Certainly the alternatives seem undesirable -teachers can also claim authority based on their age, social class, gender or ethnicity, but none of these can be supported in modern education. Charismatic authority is also possible but unpredictable: if Jacotot relied on it, it is not surprising that the method could not be duplicated or institutionalized.

However, conventional explication depends on expert insights to diagnose the difficulties and suggest effective and well-founded emancipatory remedies. The problem is that expertise also produces permanent hierarchical relations between teacher and taught, because the ignorant can never catch up and bridge the gap between themselves and their teachers. Indeed, expert pedagogues have a specialist explanation of ignorance which leads them to diagnose it in a range of behaviours, and to suspect it is ever-present. They are also constantly developing their own expertise, maintaining the gap between themselves and those progressing through earlier stages. This contradiction between emancipatory goals and hierarchical processes is the major critical theme in much of Rancière's other work, it can be argued.

\section{Misrecognising Rancière's Critique?}

Rancière himself was active in the student movement in France in 1968, and once admired Maoist practice that saw university academics forced to do manual labour, and to teach subjects in ways that were radically accessible to the masses, instead of following the normal scholarly routes to personal reward (Rancière, 1974). Rancière withdrew his support later, but 'equal intelligence' was originally a Maoist slogan (Bosteels, 2011, p. 28).

Abstracting the work on education from its context in radical politics clearly offers risks. Biesta advocates dissensus, 'an interruption of the police order' in Rancière's terms (2010, p. 59) to revitalize university politics. It is probable that he does not mean radical university politics, of the kind that Rancière once embraced, or even contemporary forms of student strikes and occupations, but without specification a call for more interest in educational politics could mean anything. After all, neoliberal policies have successfully introduced dissensus into the modern university, some of them 


\section{Harris - Rancière: Pedagogy and Politics}

in the name of disrupting the existing conservative order.

This political element of context is sometimes (mis)recognised in a more technical direction. Biesta (2010, p. 40) notes that the work on Jacotot and pedagogy is connected to 'Marxist notions of ideology and false consciousness'. However, Biesta does not pursue this critical work very far, claiming limited time and space. Biesta (2010, p. 44) refers us instead to Eagleton's textbook on ideology and quotes him as saying:

all thought is socially determined-following Karl Marx's dictum that "it is not the consciousness of men that determines their being but, on the contrary, their social being that determines their consciousness"- but also, and more importantly... ideology is thought "which denies this determination"

Biesta contrasts this reductionist economism with its usual opposite in liberal thought -- 'the assumption of the equality of all human beings' (2010, p. 57). This looks like a common rhetorical device where essential equality is opposed to a reductionist 'economism' as the only apparent alternative: the two extremes are linked in an 'ideological couplet' (Althusser \& Balibar 1975). For Marxists, essentialism is equally reductive, however, and tautological. Idealist analyses consist of endlessly 'recognizing' the selected essential quality in concrete cases, but what is defined as essential is itself really a generalization based on limited experience. Any concrete analysis can only reflect this essentialism back in a 'mirror structure', as Althusser's (1972) critique of Rousseau shows.

Rancière could also be open to the charge of essentialism: he does seem to embrace the notion of equal intelligence as 'a presupposition or axiom' (Biesta 2010, p. 51). This axiom is then constantly recognized, at work in pedagogy and utopian socialism in 1830s France, in French university politics in the 1970s, and in contemporary critiques of aesthetics, in a way that risks mirroring or tautology.

However, Rancière himself did not accept Marx's words as anything other than a preliminary polemic, and he suggests that Marx went on to argue that the classic philosophical conceptions of materialism and idealism both 'belonged to the same theoretical configuration' and needed to be opposed by a new politicized conception of materialism 'founded on the human history of production' (Rancière, 2011a, p. 12-13). 
Here and elsewhere, if we pursue these issues into Rancière's actual work, we can see the ways in which it differs from liberal educational thought. We will also not be limited to revisiting the eternal struggle between 'traditional' and 'progressive', a likely tendency noted in Biesta's article itself (Biesta 2010, p. 59).

\section{Historical studies}

Rancière's account of Jacotot's approach is clearly linked to his discussion of socialist politics in the 1830s in France. However, this work is also a critique of Marx, since neither Marx nor Engels saw potential in the forms of personal resistance or of Christian and utopian socialism that were emerging in that period, often among craftsmen and skilled workers. The reasons for this lie in the contradiction identified earlier between expert diagnosis and Marxist politics: if we consider such politics as involving an informal pedagogy to explain the implications of the theory, connections with the work on Jacotot become clear.

Those early political movements showed the critical potential that interests Rancière. In particular, some early socialists, formed around figures such as Saint-Simon and Fourier, developed the beginnings of a theory of surplus value, without referring to Marx. They noted employers' excessive annoyance at workers taking days off to celebrate 'Saint Monday', and worked out that although this saved a day's wages, absenteeism must also deprive the employer of a surplus generated by each day's labour $(2012$, p. 56). Other workers, engaged in building the new 'optical prisons', were able to record a critique of the new totalising disciplinary regimes they implied (88), as anticipations of Foucault (1977).

Above all, workers displayed aesthetic sensibilities, expressed in pride in their work, or joy in walks in the countryside, and in their dreams of a better life. What made this seditious was their demand for full recognition as human beings, for encounters with others as fully human. Those workers were able to support their challenges by exploiting the ambiguities of liberal and other humanist arguments. For Marx, and later disciples like Althusser, however, those arguments were ideological and only Marxist science would produce emancipation. 


\section{Marx and Materialism}

To deepen his critique, Rancière (2004) begins with the thesis in Marx and Engels that only the proletariat, the industrial working class organised as a mass, is capable of successful revolution against capitalism. Marx and Engels (1848) saw the growth of the proletariat as the result of a polarisation of social life, a concrete and visible contradiction, rooted in the development of modern industry with its stark divisions between workers and owners. Until this contradiction deepened, all sorts of misguided policies would emerge, where workers compromised with the bourgeois order, and these included the positions adopted by French socialists in the 1830s.

Marx certainly attacks Proudhon as an inadequate scholar, scornfully rebuking him for reducing the full impact of the radical notion of contradiction, to the banalities of bourgeois dualism: 'For him the dialectic movement is... [merely]...the dogmatic distinction between good and bad' (Marx 1847, chapter 2, 4th observation). In a subsequent letter (Marx, 1865) he remarks that misunderstandings arose inevitably from Proudhon's 'lack of German'. He goes on to add, sarcastically: 'After my expulsion from Paris Herr Karl Grün continued what I had begun [teaching Proudhon about Hegelianism]. As a teacher of German philosophy he also had the advantage over me that he himself understood nothing about it'. There is no support for ignorant schoolmasters here!

In order to achieve communism, Marx and Engels argued, the proletariat must first be prepared to lose everything, for theoretical as well as political reasons. Material circumstances determined ideas in capitalism, and even radical thought alone could never escape capitalist limits. Capitalism itself must be smashed before we can all philosophize without constraint. This critique is paradoxical, though, Rancière insists. Marxist materialism is excellent as a critical tool to expose as ideological the universalistic claims of rival philosophies, but it is open to the familiar critique that it must be an ideology itself, equally explicable as a normal worldview produced by certain social conditions.

Proletarian revolution did not take place in 1848 , so the analysis could not be validated. Worst still, in France in 1851, Napoleon III came to power and he was supported by bourgeois and worker groups, as well as financiers 
and peasants. Rancière says Marx (1852) saw Bonapartism as a failure of nerve by the bourgeoisie, who refused to assume their proper historic role as dominant class in France, even though the conditions were theoretically optimal. However, Marx came to reconsider Napoleon's regime as enabling French capitalism to modernize, to put it back on track for the eventual crisis after all, which rescued the theory, temporarily at least.

Rancière notes that Marx and Engels were still hoping that polarization and collapse would occur, well into the late 19th Century, after events such as the expansion of trade in the Americas, or the Austro-Prussian War, both of which they thought would produce deep crises. They were continually disappointed, not least by the eagerness of British workers to seek their fortunes in the gold rushes in California and Australia and to recreate the bourgeois order there.

Disillusioned, Marx threw himself into scholarly work, writing Capital as an expert, 'scientific' account for posterity. Even here, Rancière (2004) insists, Capital offers a rather odd science: it could not rely on mere facts and figures, or laws and predictions for that matter, because these arguments could be misunderstood or, worse, interpreted conventionally. It also featured political infighting -- Rancière sees the famous discussion of the secret dual nature of commodities as aimed at Proudhon's notion of worker cooperatives naively exchanging goods as much as at bourgeois political economy. As the increasingly frail Marx developed a consoling 'sacrifice ethic', in modern terms, his changing priorities became clear - he would spend his time deepening his expertise, exhaustively reading the work on agrarian ground rents, say, at the expense of any direct involvement in politics.

\section{Althusser, Science and Ideology}

In a more contemporary version of the debate, Althusser's essay on 'ideological state apparatuses' (Althusser, 1977) became well known among educationalists in particular, since it nominated the education system as one of the major apparatuses. The argument showed that ideology could be embedded in practices as well as ideas (Rancière claims that he suggested this to Althusser, and reference to 'a power organized in a number of institutions' appears in Rancière. 1974, p. 6). 


\section{Harris - Rancière: Pedagogy and Politics}

Althusser's notion of 'ideology in general' turned on the practices by which people came to think of themselves as free individuals. The education system showed the mechanism at its most effective, although Althusser borrowed terms to describe the process from the operation of the Church ('hailing'), and the legal system, ('interpellation'). The operations of these systems convinced people that they were autonomous subjects, but only at the price of acceptance of the process. To develop the educational example, more explicitly than Althusser did, students have to subject themselves to the teaching and assessment system that reserves the right to grade them, and expresses ideological values as it does so: for those who succeed, there is the gratifying sense that they have become capable, mature, autonomous individuals.

However, this essay was greeted in British radical circles with almost unanimous critique, often of an unusually personal and bitter nature. The essay left no room for any sort of resistance to the operation of the apparatuses, by radical teachers and students in particular. To quote just one influential critique (Erben \& Gleason, 1977, p. 73):

[Althusser's approach] fails to adequately address the processes through which those who work in schools may act to influence both the conditions of their work, and the wider social context of which schooling is a part...it is necessary that...teachers and students be regarded as important .

Althusser would doubtless have replied by seeing what he called 'heroic' teachers as important in a comradely and sympathetic way, but this sort of reaction is clearly humanist and thus open to the critique outlined below.

Althusser attempted to rehabilitate Marxism as a distinct science, in the face of what had been the dominant humanist trend, which was to read Marx instead as one of a number of philosophers advocating the cause of 'Man' as a free agent. Marx's early works did seem to offer a focus on the dehumanising operations of the economic system, which alienated people from each other, from the products of their labour, and from their very nature, or 'species being'. Alienation operated through a process of reification, where human constructs, like economic and social relations, took on a thing-like fixed quality, becoming seemingly immovable and 
unchangeable. However, Althusser and Balibar (1975) argued that these 'humanist' readings of Marx, including Sartre's, were mistaken, and that the early work was eventually to be rejected in favour of a more mature science, which developed distinctive concepts, especially 'mode of production'. Only these concepts enabled the scientific, valid, investigation of concrete social and political structures. Communist parties would use the findings to offer the masses the correct line in politics and steer them away from ideologies.

Rancière (2011a) offers a technical critique. Ironically echoing Marx on Proudhon, he says that the first step in domesticating Marxism is always to turn it into an abstract philosophy. This process of abstraction is seen best in Althusser's famous division between science and ideology, developed after inputs from a number of concrete sources, including a cautious account of science in the Soviet Union, yet looking as if it is a purely scholarly discovery from rereading Marx. Althusser actually relied on other bourgeois philosophers of science, especially Spinoza on 'structural causality', admitted in Althusser (1976).

Once established, the science/ideology split could then be applied to contemporary politics, such as defending the French Communist Party line, using the authority of its Marxist science against various popular forms of protest outside the Party. In particular, revolting students in May 1968 were not seen as proper revolutionaries but as promoting petty bourgeois ideologies and naïve spontaneism (Althusser, 2011). Rancière finally split with Althusser over this, seeing students in 1968 as creative thinkers offering new forms of emancipation, like their predecessors in the 1830s. Echoes of this partisanship influence his critique of Bourdieu too, as we shall see.

However, there are questions for Rancière as well. How was it that Althusser and even Marx could not see where their commitments were leading, while Rancière can? Something like a division between Rancièrian science and Marxist ideology is surely implied here? Rancière suggests that Althusser specifically turned a blind eye to some subsequent applications of his work, or even manipulated the possibilities himself, in the cause of the Party. Marx, however, incorporated personal tastes, political disappointment, and a resigned exclusion from activist politics in a way which he did not fully recognise or acknowledge. It is also possible to argue 


\section{Harris - Rancière: Pedagogy and Politics}

that Marx and Althusser both understandably misrecognized their own position, but this would be particularly ironic for Rancière, since he has little time for the concept of misrecognition, as we shall see. In Rancière's own particular case, it might have been the struggles of 1968 that provided the necessary experience to avoid misrecognition and intellectual mystification. This is workable, but it now seems that social conditions have to be right before critical intelligence or capacity develops, an important qualification to the general argument.

Rancière seems to be basing the superiority of his stance on a conception of himself as some free floating intellectual above these forms of political commitment or bias, but his own activist commitments and preferences are also clear. As an example of their influence, Rancière's persuasive 'literary' style, seen best in the historical studies, could be read as the elaborated views of a romantic reader of working class movements, finding consolation in history after his own political defeats in the 1960s and 1970s.

Rancière's aversion to the empirical, displayed well in his critique of Bourdieu, below, also leaves him rather short of current cases to analyze. He seems particularly incurious about modern examples of anarchosyndicalism, says Brown (2011), who cites arguments from modern groups for expert analysis of currently complex patterns of ownership and control instead of spontaneist movements like the workers' occupation of single factories admired by Rancière in the 1960s. As a result, the work of Marx and Althusser is being revalued by current activists.

Rancière's politics, based on the abstract axiom of equal intelligence makes it difficult to connect with other current political struggles, like those in feminism. Although his critique of Marx has helped question the centrality of class, prioritising gender could also be problematic. Mejia (nd) has argued, for example, that the specifics of the situation of groups such as black poor women tend to get lost. Their position is based on their particular experiences of colonialism, which provided a specific identity produced by a complex combination of class, 'race' and gender. This can put them at odds with more purist political positions, whether those of white women or male anti-colonialists. The same specificity, and the need to represent it in personal experience has meant they are marginalized by Rancière's theory as well, however, which speaks from a universalist position. 


\section{Bourdieu and Sociology as a Self-Serving 'Science of the Hidden'}

We can see in Rancière's critiques hints of some familiar sociological themes, for example where it is argued that Marx seems to have mediated his personal experience of reformist worker organizations through a system of pre-established elite tastes. We could easily see these tastes as habitual, that is located in a Bourdieuvian habitus, which explains their uncritical and immediate application to the issues. It is therefore surprising, perhaps, to find Rancière critiquing Bourdieu and his sociology with the same energy that he displayed in his attack on Marxism.

A structured misrecognition by the masses runs throughout all Bourdieu's work, for Rancière (2004). Universities reproduce privilege for the dominant groups, but this goes on behind the backs of those being educated in schools and in universities themselves. They are prone to see success as the result of particular 'gifts', Bourdieu and Passeron (1979) argued, although there is a hidden connection between educational success and the possession of cultural capital. Universities can thus pose as open to everyone, operating on the basis of merit alone, but they conceal how their very operations turn privilege into merit. This works so well that most people exclude themselves in advance from even applying to universities, on the familiar grounds that university 'is not for them', in a hidden correspondence between 'personal' ambition and the requirements of universities to reproduce the social relations of dominance. Rancière (2004, p. 172) sarcastically renders this as arguing that 'the examination dissimulates, in its dissimulation, the continuing elimination that dissimulates itself in the school that pretends not to eliminate'.

Seeing these processes as hidden clearly leaves a role for the expert analyst again, who alone can explain that the university curriculum is a 'cultural arbitrary' with an inexplicit and elitist pedagogy, which ignores its most obvious 'rational' purpose to communicate academic knowledge. However, Rancière argues that the analysis itself produces the entire system of misrecognition as a methodological artefact, using a combination of invalid evidence, and deeper disciplinary loyalties and dispositions.

Rancière focuses the methodological aspect of his critique on Bourdieu's (1984) massive study of leisure patterns in France, Distinction. There are familiar problems affecting all empirical studies and they can be 
found in Bourdieu's work on education too. In Distinction, the problems are central. In attempting to show how taste for music varies by social class, for example, Bourdieu did not actually play any music to respondents, but rather asked them questions about musical types. The results confirmed for Bourdieu that the masses disliked classical music (Rancière's version would doubtless render this as being unable to appreciate elite music). For Rancière however, these results ignored the complexity of actual musical tastes: he notes that there has always been much mixing of musical genres, and that classical music now appears as 'a disco hit tune, a movie soundtrack, or in the background of a commercial' (Rancière 2004, p. 186). The research itself widened social differences, and brought about 'the suppression of intermediaries, of points of meeting and exchange' (189).

These charges have been much debated in discussions of Bourdieu, and, indeed, in Bourdieu's own work. Distinction is well-provided with material for a more sympathetic reading, for example when Bourdieu acknowledges that 'certain categories were extremely heterogeneous, as regards both their objective characteristics and their preferences' (1984, p. 505). Bourdieu has surely never been a naive empiricist, and he has always said that the point is to use empirical data, with as few illusions as possible, in order to test and develop theory. It is a practical matter of trading the loss of precision for a gain in systematicity. The goal is to test hypotheses about the relations between choices in tastes as an indicator of the relations between social classes, not to offer full empirical explanations for actual tastes. He is also well aware that other methods are required, and, indeed, uses them: an initial programme of 'extended interview and ethnographic observation' (503), ongoing observations of real situations and questioning (also apparent in the work on education, in Bourdieu and Passeron, 1979, for example). Finally, there is a determined attempt to enable 'the informed reader' (1984, p. 507) to check the work for themselves. By contrast, Rancière simply asserts that all respondents must be producing 'audience effects', giving inauthentic answers designed to placate the questioner or some other imagined audience.

However, Rancière has another dimension to his critique. Regardless of any technical merits, the research depends on there being special objects of study -- symbolic practices -- which only sociology can study because they are autonomous and material enough not to be grasped by economics or 
philosophy. Bourdieu (1996, p. 73) sees the education system as having central symbolic functions too, it might be added, offering 'the rite of institution aimed at producing a separate, sacred group', a nobility, while claiming to be simply technical and rational.

In order to patrol sociology's boundaries, Bourdieu must read philosophy as ideological, especially Kantian aesthetics as we shall see. Marxism was seen as overemphasising the role of the relations of production specifically, and both Marxist economics and philosophy were recaptured by seeing them as elements of the doxa, to be studied themselves as cultural phenomena. Philosophy reproduces aristocratic tastes, and Marxism becomes part of the general disenchantment of the bourgeois world, as particular cases 'of the economy of symbolic practices' (Rancière, 2004, p. 168). In the case of the masses, however, empirical studies are required of their opinions and how they are ranked.

Rancière's methodological and political critiques are therefore linked. Bourdieu's science might reject 'positivism' or 'empiricism', but it shares their attempts to stabilize reality by developing discrete concepts and fixed 'objective' categories of social experience. In order to study special objects known only to sociological experts, social and political volatility must be contained.

A key aspect of the dispute with Bourdieu focuses on the 'Postscript: Towards a "Vulgar" Critique of "Pure" Critiques' in Bourdieu (1984). Bourdieu argues that the concepts of philosophy seem to be abstract ones, derived from carefully reading earlier philosophers, and then worked up by creative thought. However, some philosophers have clearly assumed the value of political and social circumstances in their thought - and Plato's legitimation of the Athenian social order is the favourite target here, for Bourdieu and Rancière. Philosophers imagine they can rise above the effects of their own social locations altogether. In particular Kantian theories of the aesthetic appear as:

totally ahistorical, like all philosophical thought that is worthy of the name... [It is] perfectly ethnocentric, since it takes for its sole datum the lived experience of a homo aestheticus who is none other than the subject of aesthetic discourse constituted as the universal subject of aesthetic experience (Bourdieu, 1984, p. 493) 


\section{Harris - Rancière: Pedagogy and Politics}

Theories of pure taste display 'an empirical social relation' nonetheless (Bourdieu, 1984, p. 490). An object which 'insists on being [simply] enjoyed' is particularly threatening to the essential human power of making judgments, for Kantians, because it offer 'a sort of reduction to animality, corporeality, the belly and sex' (489). Since this bodily experience "'by no means confer[s] credit or distinction upon its possessor"' (489), quoting Kant, people who enjoy it must be vulgar. This is the basis of the '[essential] opposition between the cultivated bourgeoisie and the people...barbarously wallowing in pure enjoyment' (490). A pure aesthetic is also constantly renewed as an occupational ideology for artists, and the notion of pure intellectual activity has the same effect for 'philosophy professors' who want to find their place between aristocracy and labour and so develop a legitimizing 'typically professorial aesthetic': that also explains their activities in 'hunting down historicism and sociologism' (493).

The legacy of Kantian approaches informs the current 'high aesthetic', the working system of pure taste in contemporary France that is researched and explored empirically in Distinction. Good taste is expressed in a commitment to formalism, an emotional detachment, a discerning discrimination based on an informed grasp of the formal properties of films, paintings or literature. It deliberately distinguishes itself from the 'popular aesthetic', based on emotional response, empathy and the enjoyment of content. The two approaches are illustrated by actual responses by respondents from different social classes seeing a photograph of an old woman's worn hands. A manual worker expressed immediate sympathy with the suffering represented by the gnarled fingers, whereas a Parisian (elite) engineer showed:

an aestheticising reference to painting, sculpture, or literature...[which indicates]... the neutralization and distancing which bourgeois discourse about the social world requires and performs. "I find this a very beautiful photograph...It puts me in mind of Flaubert's old servant-woman"' (Bourdieu, 1984, p. 45).

Rancière (2004) explains away the worker's response as an audience effect again. For him, Kant is being tactically re-read by Bourdieu to set up criteria which can be tested, and Rancière sees this as positivist and wholly 
inappropriate. As before, the method squeezes out any heterogeneity or mixing of tastes. There is no recognition of struggles to recuperate minor cultures or desacralize higher ones. Bourdieu seems unaware of past efforts to popularize elite culture, and he dismisses efforts the other way around, so to speak. When rebellious students in 1968 demanded to study popular texts on their university courses, for example, Bourdieu saw this only as a confirmation of class tastes in students, wanting to take revenge on their professors, or a confirmation of the superior tastes of the most knowledgeable bourgeois, who can manage vulgarity. Although Bourdieu might disapprove of the system that upholds the opposition 'between the cultivated bourgeoisie and the people' (Bourdieu 1984, p. 490), he comes to support this opposition nonetheless.

\section{Aesthetics}

Above all, aesthetic sensibility can never be reduced to social class closure nor domesticated by the language of sociologists. Rancière (2002) was to develop the notion of the aesthetic as an autonomous area offering a unique medium open to all. To summarize this extensive work, Rancière (2011b) begins with a critique of radical forms of theatre that set out to involve the audience. There we find the same division between the ignorant and the knowledgeable, preserved even while attempting to undermine it. The book goes on to argue that visual images offer the most democratic form, offering the most accessible 'pensive images', (which provoke subjective thought in the viewer), acting as the 'third things' discussed in the work on pedagogy. There is also admiration for modern non-representational art forms as having escaped conventions which then opens possible responses. Art has become autonomous as far as social relations are concerned, and is therefore potentially universal.

This work has inspired some recent radical experiments in aesthetic education and pedagogy. Rancière's views are contrasted favourably with those of Freire, for example (Lewis, 2011). Freire uses images in his 'culture circles', but wants them to be decoded in a prescribed manner, Lewis argues, rather than seeing students as 'creative interpreters and translators' (2011, p. 39). This contradicts Freire's democratic goals just as in radical theatre. Lewis suggests instead that performance or installation art 


\section{Harris - Rancière: Pedagogy and Politics}

offers a more promising form of open and emancipatory education.

More conventionally, Lambert (2011) describes her project aiming 'to unsettle and redistribute social, cultural, political and economic power geometries' and to construct different knowledge spaces at Warwick University, UK. Rancière's work provided 'rich theoretical resources' (2011, p. 42), prompting thinking about how to transform classrooms to produce different 'visceral and emotional affects'. Breaking with traditional ways to present research findings, a multimedia exhibition format was adopted instead in a new 'sensual space' (34). Students themselves had to make decisions about how to use the space in different situations. Effects were mixed and limited by the overall conventions of the University, but teachers and students were prompted to think differently about knowledge and about their roles, Lambert claims.

Rancière (2002) himself comes closes to recognising the need for some sort of pedagogic intervention in these encounters, since there is a paradox in contemporary art. It is autonomous enough to remain critical of popular taste, but artistic works can become heteronomous, alien, inaccessible to the public, which blocks critical impact. Some sort of expert explanation is required to provide public access, but that would require the public to submit to a hierarchical relation as they would need to learn something of the specialist terminology of art and art criticism. Rancière does not immediately dismiss any expert intervention here as reproducing ignorance in the name of the 'police order'. Instead, he acknowledges that there might be a "certain undecidability in the "politics of aesthetics"' (2002, p. 151). Radical populism is not the only way to proceed in this case. He can only suggest we should proceed by 'playing a heteronomy against an autonomy [and vice versa]... Playing one linkage between art and non art against another such linkage' (150).

This looks rather abstract but it might inform the specific proposals in Pelletier and Jarvis (2013) discussing creative writing courses. They note that Rancière has also argued for the value of preserving some conventional artistic forms, like the narrative structure of novels, against fully avantgarde works that risked immediate rejection as incomprehensible. Realist narrative in particular might be retained because it provides some sort of 'molar' structure within which more challenging 'expressive' moments might be included. Overall, this is surely the familiar notion of 'optimal 
challenge' in modern pedagogy, preserving a tactical balance between the familiar and unfamiliar. Rancière needs to revise his conception of pedagogy more generally, in both educational and political contexts, and investigate empirical practices.

\section{Rancière's Method}

Rancière's methodology rules out conventional empirical investigations, however. Interpreting the historical material can be taken as an illustration. Biesta (2010) identifies the method as involving the merging of voices, but this style is not used in all the other works, especially the critiques of rival approaches. Instead, Rancière's method is better grasped as a kind of 'deconstruction' (Reid's Introduction to Rancière, 2012) borrowed from Foucault, as we shall argue below.

Commenting on his own historical writing style, Rancière (2006, p. 20) says it was:

necessary to blur the boundaries between empirical history and pure philosophy; the boundaries between disciplines and the hierarchies between levels of discourse. .. It was not a case of the facts and their interpretation... what it came down to me to do was a work of translation, showing how these tales of springtime Sundays and the philosopher's dialogues translated into one another. It was necessary to invent the idiom appropriate to this translation and countertranslation...this idiom could only be read by those who would translate it on the basis of their own intellectual adventure.

It is also clear that Rancière is not claiming any positive concrete findings from his historical review. These would be "impossible" (Reid's Introduction to Rancière, 2012, p. xxviii), because there could be no science of the emergence of socialism, and no attempt to represent with privileged categories the voices of the excluded and voiceless. The only alternative was to offer a knowledge that at least resists the dominant tendencies to 'smother' anything which is insupportable in conventional terms.

This is obviously close to Foucault's attempt to organize 'an insurrection of subjugated knowledges', (Foucault 1980, p. 81) designed to: 
entertain the claims to attention of local, discontinuous, disqualified, illegitimate knowledges against the claim of a unitary body of theory which would filter, hierarchise and order them in the name of some true knowledge and some arbitrary idea of what constitutes a science and its objects (83).

Foucault's critique of positivism is also evident in Rancière's discussion of Marxist science, suggesting, more or less, that modern sciences emerge as discourses uniting different elements of language, practice and institutions. Discursive objects have their own rules of ordering, as 'practices that systematically form the objects of which they speak' (Foucault, 1974, p. 49). Discursive formations relate together the formation of objects, concepts, subject positions and strategic choices (116). Specifically, Foucault (1979, p. 38) argues that we should attempt to uncover discursive formations as 'systems of dispersion, regularities in choices', rather than operate with categories such as science or ideology.

As a source of critique, Foucault could undermine any discourses claiming universality, including Marxism, by restoring 'the system of practical and discursive constraints that allowed [them] to be uttered at all'. This critique is itself an example of 'the expressions through which the struggle and questions of our present seek to give voice to a new freedom' (Rancière, 2011a, 124), so discursive undermining becomes a kind of political struggle in theory after all. Without immediate political relevance, Rancière once saw philosophy as merely the 'hum of cultural chit chat' (Rancière 2011a, p. 113). Rancière's early political positions included Maoism as we have seen, and then 'workerist humanism' (Reid in Rancière, 2012). In the ensuing absence of opportunities to practise his own radical politics, perhaps Foucault helped provide a more abstract and academic alternative in the politics of discourses.

A discursive turn could also underpin Rancière's demand for radical equality if we see that it is discourses, not individuals, which are fundamentally equal. Discourses construct their own objects and explanations, and there can be no hidden dimension that sociologists or Marxists can investigate to explain them. Individuals might suffer from amnesia about the processes of discursive construction, requiring the service of a geneaologist, but discourses must always be transparent to themselves ultimately. This 'nominalism' (Bosteels, 2011) also produces a 
serious problem with relativism as we shall see.

Modern politics is now a matter of forming up dissenting discourses to challenge boundaries established by conventional divisions of labour, especially the mental/manual split. Rancière says this will disrupt 'the police order'. Biesta (nd) translates this into an abstract struggle for inclusion in education more generally, a right to have one's voice heard despite discourses which disqualify. Rancière's principles are unable to distinguish between these discourses, however, and could be used to support widely differing positions as we suggested. More generally, a dilemma familiar to any practising pedagogue awaits in deciding whether to include even those voices that would themselves not tolerate others.

Problems with Foucault and his politics can only be discussed briefly. DeCerteau (1984) seems particularly appropriate here in connecting the methodological and the political again. Optical and panoptical procedures dominate Foucault's more concrete accounts, for example, and these procedures somehow emerge from a huge mass of detailed policies and plans. But what privileges these particular procedures? For DeCerteau, Foucault himself imposes coherence through the exhaustive nature of details gathered from different sources, which leads to implicit claims for universality. The key technique to manage and domesticate details is narrative, but narrative skill is a matter of discernment or taste (which would obviously give Bourdieu an opening). Foucault renders his work as research which pretends to be 'eclipsed by the erudition and the taxonomies that [his theory] manipulates' (1984, p. 80). Foucault and Rancière are both very good at using rhetoric and detailed description -- 'he [Foucault] makes what he says appear evident to the public he has in view' (79).

For Baudrillard (1987), after Foucault everything became 'politics', and so nothing distinctive could be studied. When Foucault announced that power was dispersed through social life, it became inexplicable and untraceable -- it disappeared. Well organized and well resourced politicians will continue to dominate the politics of effective compulsion, without even bothering to claim any symbolic dimensions to their activities. Baudrillard (1987) says that Foucault (and Rancière, and perhaps even Biesta) seem to be assuming some Deleuzian notion of a universal, pulsating, abstract desire to make sense of the world, to produce unconventional and rhizomatic discourses, but apathy is far more common among the masses, 
and should be seen as a political strategy itself.

\section{Conclusion}

Rancière's extensive work in a number of fields can be seen as offering an important form of immanent critique, questioning whether egalitarian and emancipatory proposals still leave sources of inequality unexamined. Whether classic French school explication is widespread in a modern education system is in doubt, but current pedagogies still need analysis to decide whether they preserve a permanent distinction between the knowledgeable and the ignorant.

The same points extend to radical theorising - even systematic and insightful thinkers like Althusser, Bourdieu, Freire and Marx can still produce contradictions and paradoxes. Marxism clearly has a transformative emancipatory potential, and Mills (2008) demonstrates a similar one in Bourdieu. However, Rancière points to a pedagogic form of authoritarianism in both, where the very categories central to the transformative process are available only to academic experts. However, these contradictions really need to be actively investigated in concrete circumstances, rather than insisting on a fundamental commitment to equal intelligences as a safeguard.

There is an axiomatic and rather abstract and purist element in Rancière's work, and a scholastic relativism in addressing the nonaxiomatic. This helps him develop uncompromising critiques of any position - but compromises are inevitable in concrete circumstances, and abstract critique misses that some positions are more liberating than others. Most of the writers he discusses operate with the paradoxes of attempting to work within unequal systems, rather than opting for utopian solutions, and this also includes most practising pedagogues. The debate with Bourdieu shows the options. Bourdieu operates with the data on inequality that he can access and with empirical techniques that have known flaws and limits. Rancière's axiom of equal intelligence stays uncontaminated by any such flaws but he can offer only rhetoric and essentialist recognitions, using case-studies, often of exceptional individuals.

Finally, many pedagogues would see the main site of workplace despotism these days in neoliberal managerial regimes, and Foucaldian and 
Rancièrian analysis would be useful as a source of critique to deny their claims to universality. Rancière's historical work might encourage pedagogues and students to demand that they are treated as knowledgeable human beings with a right to leisure and an aesthetic life, as much as did the workers in France in the 1830s. Rediscovering the 'equal intelligence' of educational personnel against managerial expertise could be useful to show alternatives.

\section{References}

Althusser, L. (1969). For Marx. Harmondsworth: Penguin Books.

Althusser, L. (1972). Politics and History, Part 2. New Left Books:

London.

Althusser, L. (1976). Essays in Self - Criticism. New Left Books.

Althusser, L. (1977). Ideology and Ideological State Apparatuses (Notes

Towards an Investigation). In his Lenin and Philosophy and Other

Essays (pp. 122-76). London: New Left Books.

Althusser, L. (2011). Student problems. Radical Philosophy, 170, 8-15.

Althusser, L. \& Balibar, E. (1975). Reading Capital. London: New Left Books.

Baudrillard, J. (1987). Forget Foucault. New York: Semiotext(e) Foreign Agents.

Biesta, G. (2010). A New Logic of Emancipation: the Methodology of Jacques Rancière. Educational Theory, 60, 39--59. doi: 10.1111/j.1741-5446.2009.00345.x

Biesta, G. (nd) Democracy, Education and the Question of Inclusion. University of Exeter, School of Education and Lifelong Learning, Heavitree Road, Exeter, EX1 2LU.

Bosteels, B. (2011). Reviewing Rancière. Or, the persistence of discrepancies. Radical Philosophy 170, 25-31.

Bourdieu, P. (1984). Distinction: a social critique of the judgment of taste. London: Routledge.

Bourdieu, P. (1988). Homo Academicus. Cambridge: Polity Press.

Bourdieu, P. (1996) The State Nobility, with the collaboration of Monique De Saint Martin. Cambridge: Polity Press. 
Bourdieu, P. \& Passeron, J--C. (1979). The Inheritors: French students and their relation to culture. Chicago: University of Chicago Press.

Brown, N. (2011). Red years. Althusser's lesson, Rancière's error and the real movement of history. Radical Philosophy, 170, 16 - 24.

De Certeau, M. (1984). The Practice of Everyday Life. University of California Press: Berkeley.

Erben, M. \& Gleason, D. (1977). Education as Reproduction: A critical examination of some aspects of the work of Louis Althusser. In M. Young \& G. Whitty (Eds.) Society, State and Schooling, (pp. 7392), Ringmer: The Falmer Press.

Foucault, M. (1974). The Archaeology of Knowledge. London: Tavistock Publications.

Foucault, M. (1977). Discipline and Punish: the birth of the prison. London: Penguin Books.

Foucault, M. (1980). Power/Knowledge. Selected interviews and other writings 1972-1977. Brighton: Harvester Press.

Lambert, C. (2011) Psycho classrooms: teaching as a work of art. Social and Cultural Geography 12, 27--45. doi: 10.1080/14649365.2010.542479

Marx, K. (1847). The Poverty of Philosophy. Retrieved from https://www.marxists.org/archive/marx/works/1847/povertyphilosophy/ch02.htm

Marx, K. (1852). The Eighteenth Brumaire of Louis Bonaparte. Retrieved from http://www.marxists.org/archive/marx/works/1852/18thbrumaire/

Marx, K. (1865). On Proudhon: Letter to JB Schweizer. Retrieved from http://www.marxists.org/archive/marx/works/1865/letters/65_01_24 .htm

Marx, K. \& Engels, F. (1932) [1845-6] The German Ideology. Retrieved from http://www.marxists.org/archive/marx/works/1845/germanideology/

Marx, K. \& Engels, F. (1848). Manifesto of the Communist Party. Retrieved from https://www.marxists.org/archive/marx/works/1848/communistmanifesto/ 


\section{RISE - International Journal of Sociology of Education, 4(2) 181}

Mejia, L. (nd). We speak in Tongues: A Woman of Colour Critique of Jacques Rancière's Political Subject. Retrieved from http://www.academia.edu/3575255/_We_Speak_In_Tongues_A_W oman_of_Colour_Critique_of_Jacques_Rancières_Political_Subjec

Mills, C. (2008). Reproduction and Transformation of the Inequalities of Schooling: the transformative potential of the theoretical constructs of Bourdieu. British Journal of Sociology of Education 29, 79-89. doi:10.1080/01425690701737481

Pelletier, C. \& Jarvis, T. (2103). The Paradoxical Pedagogy of Creative Writing.' In O. Davies (Ed.) Rancière Now, (pp. 85-100), Cambridge: Polity Press.

Rancière, J. (1974). On the theory of ideology (the politics of Althusser). Radical Philosophy 7, 2-15.

Rancière, J. (1991). The Ignorant Schoolmaster: Five Lessons in Intellectual Emancipation. Stanford: Stanford University Press.

Rancière, J. (2002). The aesthetic revolution and its outcomes: emplotments of autonomy and heteronomy. New Left Review 14, Mar. - Apr.

Rancière, J. (2003). Politics and Aesthetics: an interview. Angelaki 8(2) $191-21$.

Rancière, J. (2004). The Philosopher and His Poor. Durham: Duke University Press.

Rancière, J. (2006). Thinking between disciplines: an aesthetics of knowledge. Parrhesia 1, 1-12.

Rancière, J. (2011a) Althusser's Lesson. London: Continuum International Publishing.

Rancière, J. (2011b). The Emancipated Spectator. London: Verso.

Rancière, J. (2012). Proletarian Nights: The Workers' Dream in Nineteenth Century France. London: Verso.

David Ernest Harris is Emeritus professor at University of St Mark and St John.

Contact Address: Direct correspondence to David Ernest Harris at University of St Mark and St John, Derriford Road, Plymouth, Devon PL6 8BH, United Kingdom. E-mail: darrisuk@gmail.com 